\title{
UPAYA MENINGKATKAN HASIL BELAJAR IPS DENGAN MENERAPKAN MODEL ROLE PLAYING BERBANTUAN MEDIA PAPAN FLANEL PADA PESERTA DIDIK KELAS IV-C SDN-1 SABARU PALANGKARAYA TAHUN PELAJARAN 2016/2017
}

\author{
Oleh : Orhan, M.Pd* dan Siti Aminah*
}

\begin{abstract}
Abstrak
Penelitian ini bertujuan untuk: 1) Untuk mendeskripsikan aktifitas belajar peserta didik dalam pembelajaran IPS dengan menerapkan model role playing berbantuan media papan flanel pada kelas IV-C SDN-1 Sabaru Palangkaraya Tahun Pelajaran 2016/2017. 2) Untuk meningkatkan hasil belajar peserta didik dalam pembelajaran IPS dengan menerapkan model role playing berbantuan media papan flanel pada kelas IV-C SDN-1 Sabaru Palangkaraya Tahun Pelajaran 2016/2017.Jenis penelitian yang digunakan peneliti adalah Penelitian Tindakan Kelas (PTK), dengan subjek penelitian seluruh peserta didik kelas IV-C SDN-1 Sabaru Palangkaraya berjumlah 26 orang peserta didik. Teknik pengumpulan data dalam penelitian ini menggunakan tes dan observasi.Analisis data menggunakan analisis data kualitatif dan kuantitatif. Hasil penelitian ini menunjukkan bahwa: 1) keaktifan belajar IPS peserta didik kelas IV-C SDN-1 Sabaru Palangkaraya meningkat dengan rata-rata 3,43 yang termasuk kriteria baik. 2) hasil belajar peserta didik kelas IV-C SDN-1 Sabaru Palangkaraya meningkat dari hasil pre test rata-rata nilai 62,11 dengan ketuntasan klasikal $46,15 \%$, sedangkan hasil post test siklus I rata-rata nilai 76,53 dengan ketuntasan klasikal $100 \%$.
\end{abstract}

Kata Kunci : Model role playing, media papan flanel, aktivitas peserta didik, hasil belajar IPS.

\begin{abstract}
This study aims to describe the learning activities of students in social studies learning by applying role-playing models assisted by flannel board media in class IV-C SDN-1 Sabaru Palangkaraya 2016/2017 Academic Year, as well as improving student learning outcomes in social studies learning by applying role models playing aided by flannel board media in class IV-C SDN-1 Sabaru Palangkaraya Academic Year 2016/2017. The type of research used by researchers is Classroom Action Research (CAR), with the research subjects all IV-C class students of SDN-1 Sabaru Palangkaraya totalling 26 students. Data collection techniques in this study used tests and observations. Data analysis using qualitative and quantitative data analysis. The results of this study indicate that the activity of social studies learning students of class IV-C of SDN-1 Sabaru Palangkaraya increased by an average of 3.43 which included good criteria, learning outcomes of students of class IV-C of SDN-1 Sabaru Palangkaraya increased from the pretest results the value of 62.11 with classical completeness was $46.15 \%$, while the post-test results in the first cycle averaged 76.53 with $100 \%$ classical completeness.

Keywords : Model role playing, flannel board media, student activity, social studies learning outcomes.
\end{abstract}




\section{PENDAHULUAN}

Ilmu pengetahuan sosial, yang sering disingkat dengan IPS, adalah ilmu pengetahuan yang mengkaji berbagai disiplin ilmu sosial dan kegiatan dasar manusia yang dikemas secara ilmiah dalam rangka memberi wawasan dan pemahaman yang mendalam kepada peserta didik, khususnya di tingkat dasar dan menengah. IPS adalah untuk mengembangkan konsep pemikiran yang berdasarkan realita kondisi sosial yang ada di lingkungan peseta didik, sehingga dengan memberikan pendidikan IPS diharapkan dapat melahirkan warga negara yang baik dan bertanggung jawab terhadap bangsa dan negaranya. Pendidikan IPS saat ini dihadapkan pada upaya peningkatan kualitas pendidikan khususnya kualitas sumber daya manusia, sehingga eksistensi pendidikan IPS benar-benar dapat mengembangkan pemahaman konsep dan keterampilan berpikir kritis.Berkaitan dengan hal tersebut, pendidikan nasional harus dikembangkan secara terpadu, serasi dan bersinambung. Untuk mencapai tingkat pendidikan yang diinginkan, maka cara yang harus ditempuh adalah melalui usaha belajar, baik di sekolah maupun dirumah dapat kita kembangkan berbagai macam pengetahuan, keterampilan, potensi pribadi dan kecakapan. Pendidikan yang diperlukan dan ada di sekolah salah satunya adalah pendidikan Ilmu Pengetahuan Sosial (IPS).

Pembelajaran adalah suatu upaya yang dilakukan oleh seorang guru atau pendidik untuk membelajarkan peserta didik yang belajar. Menurut pendapat Miarso (Siregar, 2010: 12-13), menyatakan bahwa pembelajaran adalah "usaha pendidikan yang dilaksanakan secara sengaja, dengan tujuan yang telah ditetapkan terlebih dahulu sebelum proses dilaksanakan, serta pelaksanaannya terkendali”. Pada pendidikan formal (sekolah), pembelajaran merupakan tugas yang dibebankan kepada guru, karena guru merupakan tenaga profesional yang dipersiapkan.Berdasarkan observasi di lapangan yakni di SDN-1 Sabaru Palangkaraya yang dilakukan pada bulan November 2016 sebanyak 3 kali. Terdapat fakta di lapangan pada saat proses pembelajaran IPS hasil belajar peserta didik masih rendah, guru masih kurang bervariasi menggunakan metode dan model pembelajaran dan kurangnya alat bantu pembelajaran yaitu media, sehingga sebagian peserta didik kurang tertarik pada pembelajaran IPS. Hal tersebut ditunjukkan pada saat pembelajaran IPS peserta didik hanya mendengarkan, kurang aktif, kurangnya pemahaman pada materi, kurangnya interaksi peserta didik kepada guru pada saat pembelajaran berlangsung, setiap ditanya mengenai materi tersebut hanya sebagian peserta didik yang bisa menjawab dan orangnya hanya itu-itu saja. Hal ini berdampak pada hasil belajar peserta didik yang rendah yaitu di bawah kriteria ketuntasan minimum (KKM). Peserta didik kelas IV-C berjumlah 26 peserta didik, hanya 9 orang (35\%) peserta didik yang memperoleh nilai sesuai atau di atas kriteria ketuntasan minimum pada mata pelajaran IPS. Sedangkan 17 orang $(65 \%)$ peserta didik memperoleh nilai di bawah kriteria ketuntasan minimum (KKM) pada mata pelajaran IPS di SDN1 Sabaru Palangkaraya yang telah di tetapkan yaitu 70 .

Berdasarkan pengamatan bahwa penyebab hal tersebut karena beberapa 
faktor yaitu, pada proses pembelajaran guru masih kurang bervariasi menggunakan metode dan model pembelajaran, guru terpaku pada buku dan kurangnya perhatian kepada peserta didik, kurangnya media pembelajaran atau alat bantu pada pembelajaran IPS, maka dari itu guru perlu model dan media pembelajaran untuk meningkatkan hasil belajar peserta didik kelas IV-C SDN-1 Sabaru Palangkaraya.

Berdasarkan uraian permasalahan di atas, maka dari itu cara mengatasi permasalahan tersebut, diperlukan adanya model role playing atau model bermain peran yang mengutamakan aktivitas menyenangkan peserta didik dan berbantuan media pembelajaran papan flanel diharapkan dapat meningkatkan keaktifan serta minat peserta didik dalam proses pembelajaran IPS dan mampu mencapai tujuan pembelajaran.

Menurut Komalasari (2013: 80) role playing adalah "suatu model penguasaan bahan-bahan pelajaran melalui pengembangan imajinasi dan pengahayatan peserta didik".

Menurut Komalasari (2013: 81), Langkah-langkah role playing antara lain sebagai berikut:

Langkah 1 : Guru menyusun/menyiapkan skenario proses yang akan ditampilkan.

Langkah 2 : Menunjuk beberapa peserta didik untuk mempelajari skenario dalam waktu beberapa hari sebelum pembelajaran.

Langkah 3 : Guru membentuk kelompok peserta didik yang beranggotakan 5 orang.
Langkah 4 : Memberikan penjelasan tentang kompetensi yang ingin dicapai.

Langkah 5 :Memanggil para peserta didik yang sudah ditunjuk untuk melakonkan skenario yang sudah dipersiapkan.

Langkah 6 :Masing-masing peserta didik berada dikelompoknya sambil mengamati skenario yang sedang diperagakan.

Langkah 7 : Setelah selesai ditampilkan, masing-masing peserta didik diberikan lembar kerja untuk membahas penampilan masing-masing kelompok.

Langkah 8 :Masing-masing kelompok menyampaikan hasil kesimpulannya.

Langkah 9 :Guru memberikan kesimpulan secara umum.

Menurut Huda (2013: 210), adapun kelebihan model pembelajaran role playing ini adalah:

1) Dapat memberikan kesan pembelajaran yang kuat dan tahan lama dalam ingatan peserta didik.

2) Bisa menjadi pengalaman belajar menyenangkan yang sulit untuk dilupakan.

3) Membuat suasana kelas menjadi lebih dinamis dan antusias.

4) Membangkitkan gairah dan semangat optimisme dalam diri peserta didik serta menumbuhkan rasa kebersamaan.

5) Memungkinkan peserta didik untuk terjun langsung memerankan sesuatu yang akan dibahas dalam proses belajar. 
Menurut Huda (2013: 211), adapun kelemahan dari model pembelajaran role playing ini adalah:

1) Banyaknya waktu yang dibutuhkan.

2) Kesulitan menugaskan peran tertentu kepada peserta didik jika tidak dilatih dengan baik.

3) Ketidakmungkinan menerapakan rencana pembelajaran jika suasana kelas tidak kondusif

4) Membutuhkan persiapan yang benarbenar matang yang akan dihabiskan waktu dan tenaga.

5) Tidak semua materi pelajaran dapat disajikan.

Menurut Kustandi dan Bambang Sutjipto (2013: 46-47), papan flanel adalah: papan flanel (flanel board) merupakan media visual yang efektif untuk menyajikan pesan tertentu kepada sasaran tertentu pula, salah satunya kepada peserta didik. Gambar-gambar yang disajikan dapat dipasang dan dilepas dengan mudah, sehingga dapat berkali-kali dipakai.

Menurut Kustandi dan Bambang Sutjipto (2013: 47), ada beberapa kelebihan dari media visual papan flanel adalah sebagai berikut:

a) Papan flanel dapat dibuat sendiri oleh guru.

b) Dapat dipersiapkan terlebih dahulu dengan teliti

c) Dapat memusatkan perhatian peserta didik terhadap suatu masalah yang dibicarakan

d) Dapat menghemat waktu pembelajaran, karena segala sesuatu sudah dipersiapkan dan peserta didik dapat melihat sendiri secara langsung.

Menurut Kustandi dan Bambang Sutjipto (2013: 47), selain kelebihan ada beberapa kekurangan dari media visual papan flanel adalah sebagai berikut:

a) Walaupun bahan flanel dapat menempel pada sesamanya, tetapi hal ini tidak menjamin pada bahan yang berat karena dapat lepas bila di tempelkan.

b) Bila terkena angin sedikit saja, bahan yang ditempel pada papan flanel tersebut akan berhamburan jatuh.

\section{Metode Penelitian}

Penelitian ini menggunakan rancangan Penelitian Tindakan Kelas (PTK).Mertler (2014: 4), menjelaskan penelitian tindakan adalah "penyelidikan sistematis apa pun yang dilakukan oleh para pendidik dengan tujuan mengumpulkan informasi tentang bagaimana sekolah-sekolah khusus beroperasi, bagaimana mereka mengajar, dan bagaimana peserta didik belajar".

Dalam penelitian, kehadiran peneliti mutlak diperlukan karena kehadiran peneliti sangat diperlukan dalam setiap kegiatan di tempat penelitian.Peneliti berperan sebagai perencana, pelaksana tindakan, pengamat, reflektor dan sebagai pelapor hasil penelitian.

Subjek yang menjadi penelitian adalah peserta didik kelas IV-C SDN-1 Sabaru Palangkaraya yang berjumlah 26 orang yang terdiri dari 14 laki-laki dan 12 perempuan.

Teknik pengumpul data yang digunakan pada penelitian ini yaitu observasi dan tes.

Menurut Kunandar (2012: 143), menjelaskan observasi adalah "kegiatan pengamatan (pengambilan data) untuk memotret seberapa jauh efek tindakan telah mencapai sasaran".

Menurut Arikunto (Sangadji dan Sopiah, 2010: 150), bahwa tes adalah 
"serentetan pertanyaan dan latihan serta alat lain yang digunakan untuk mengukur keterampilan, pengetahuan intelegensi, kemampuan, atau bakat yang dimiliki oleh individu atau kelompok".

Data yang dikumpulkan dari setiap kegiatan yang akan dilaksanakan dalam siklus PTK dianalisis secara deskriptif dengan menggunakan teknik presentase untuk melihat kecenderungan yang terjadi dalam pembelajaran. data yang diperoleh melalui instrument sebelumnya diolah lebih dulu menjadi dua jenis yaitu data kualitatif dan kuantitatif.

Data kualitaif digunakan untuk memberi keterangan tentang proses pembelajaran. Sedangkan data kuantitatif digunakan untuk mengetahui jumlah peningkatan hasil belajar peserta didik setelah proses pembelajaran menggunakan model pembelajaran role playing berbantuan media papan flanel.

\section{Hasil Penelitian dan Pembahasan}

Pelaksanaan tindakan pada pembelajaran IPS dengan menerapkan model pembelajaran role playing berbantuan media papan flanel pada materi aktivitas ekonomi dan sumber daya alam yang dilaksanakan di SDN-1 Sabaru Palangkaraya diperoleh dari hasil pengamatan lembar observasi guru dan peserta didik yaitu dari dua pengamat menunjukkan bahwa untuk aktivitas guru dengan nilai rata - rata 3,25 dengan kriteria baik dan peserta didik dengan nilai rata - rata 3,43 dengan kriteria baik.

Selain dari dua pengamat pada saat proses pembelajaran berlangsung guru (peneliti) mengamati empat aspek pada saat peserta didik memperagakan atau melakonkan skenario. Empat aspek tersebut yaitu keseriusan, tutur kata, keberanian dan konsep dengan kriteria 3 mampu, 2 cukup mampu, 1 kurang mampu. Dari 26 peserta didik terbagi menjadi 5 kelompok yang dimana kelompok 1 beranggotakan 5 orang peserta didik, kelompok 2 beranggotakan 5 orang peserta didik, kelompok 3 beranggotakan 5 orang peserta didik, kelompok 4 beranggotakan 6 orang peserta didik, kelompok 5 beranggotakan 5 orang peserta didik, dari kelompok 1 sampai dengan 5 kelompok mendapat kriteria cukup mampu akan tetapi untuk rata-rata tertinggi diperoleh oleh kelompok 1 yaitu 2,75 dengan kriteria cukup mampu.

Hasil belajar peserta didik pada mata pelajaran IPS. Pada tes awal (pre test), belum menerapkan model role playing berbantuan media papan flanel hasil belajar peserta didik memperoleh nilai rata-rata 62,11 (dibawah KKM yaitu 70) dan dengan ketuntasan klasikal 46,15\%. Dengan menerapkan model roleplaying berbantuan media papan flanel pada siklus I memperoleh nilai rata-rata 76,53 dengan ketuntasan klasikal 100\%. Diatas adalah diagram grafik yang menunjukkan persentase peningkatan hasil belajar ilmu pengetahuan sosial (IPS) pada saat pra tindakan dan pelaksanaan tindakan siklus I.

\section{Kesimpulan}

1. Aktivitas belajar peserta didik dalam pembelajaran IPS dengan menerapkan model pembelajaran role playing berbantuan media papan flanel pada kelas IV-C SDN-1 Sabaru Palangkaraya Tahun Pelajaran 2016/2017, menjadi baik karena peserta didik aktif, lebih bersemangat, memperhatikan penjelasan guru, mengikuti petunjuk guru untuk 
membentuk kelompok, melakonkan skenario yang sudah dibagikan guru, dapat bekerja sama dengan teman, dan peserta didik juga menjadi lebih berpartisipasi di dalam proses pembelajaran. Dengan hasil pengamatan memperoleh skor rata-rata 3,43, dengan kriteria baik.

2. Ada peningkatan hasil belajar IPS dengan menerapkan model pembelajaran role playing berbantuan media papan flanel pada kelas IV-C SDN-1 Sabaru Palangkaraya Tahun Pelajaran $2016 / 2017$. Peningkatan tersebut dapat dilihat dari hasil belajar peserta didik khususnya mata pelajaran IPS. Pada siklus I perolehan nilai rata-rata peserta didik yaitu 76,53 dengan ketuntasan klasikal 100\%. Dengan menerapkan model role playing berbantuan media papan flanel ini diterapkan untuk mengembangakn kreativitas dan minat belajar peserta didik baik secara individu dan kelompok karena model role playing ini membantu agar peserta didik dapat lebih bekerjasama selain itu bisa juga menjadi pengalaman belajar yang menyenangkan.

\section{Daftar Pustaka}

Komalasari, Kokom. 2013. Pembelajaran Kontekstual Konsep dan Aplikasi. Bandung: PT Refika Aditama.

Kustandi, Cecep. Bambang, Sutjipto. 2013. Media Pembelajaran Manual dan Digital. Bogor: Ghalia Indonesia

Kunandar. 2012. Penelitian Tindakan Kelas. Jakarta: RajaGrafindo Persada.
Mertler, Craig A. 2014. Penelitian Tindakan Kelas. Jakarta: Indeks.

Sangadji, Etta Mamang. Sopiah.2010. Metodologi Penelitian Pendekatan Praktis dalam Penelitian. Yogyakarta: CV Andi Offset.

Siregar, Eveline. Hartini, Nara. 2010. Teori Belajar dan Pembelajaran. Bogor: Ghalia Indonesia 